\title{
Pengaruh Pelatihan Komunikasi Interpersonal terhadap Peningkatan Kualitas Hubungan Sosial Mahasiswa Baru
}

\author{
Eva Palupi \\ IAIN Salatiga, Jawa Tengah, Indonesia
}

evapalupi77@gmail.com

\begin{abstract}
Abstrak
Meskipun dikatakan sebagai makhluk yang sempurna, manusia juga memiliki keterbatasan-keterbatasan. Manusia menjalin hubungan sosial atau hubungan dengan manusia lain adalah sebagai upaya memenuhi kebutuhan atau keterbasannya. Hubungan sosial pada mahasiswa baru memiliki peran penting dalam keberhasilan dan kesejahteraan psikologis mahasiswa. Namun demikian, banyak persoalan yang mewarnai proses hubungan sosial khususnya pada mahasiswa baru. Banyak penelitian telah memberikan data bahwa pelatihan komunikasi interpersonal dapat meningkatkankan hubungan sosial. Penelitian ini ingin mengetahui bagaimanakah dampak pelatihan komunikasi interpersonal terhadap kualitas hubungan sosial pada mahasiswa baru di lingkup IAIN Salatiga. Penelitian ini menggunakan menggunakan metode quasi eksperimen dengan melibatkan kelompok kontrol dan kelompok eksperimen. Subyek dalam penelitian ini adalah mahasiswa baru, berjumlah 21 orang (7 laki-laki dan 14 perempuan) pada kelompok eksperimen dan 20 mahasiswa (9 laki-laki dan 11 perempuan) pada kelompok kontrol. Hasil penelitian ini menunjukkan bahwa terdapat perubahan yang signifikan atas kualitas hubungan sosial pada mahasiswa baru sebelum pelatihan dan sesudah penelitian $(\mathrm{t}=2.75, \mathrm{p}<0.01)$. Terdapat perbedaan skor kualitas hubungan sosial antara kelompok eksperimen dan kelompok kontrol setelah 1 bulan pelatihan, dimana skor kualitas hubungan sosial pada kelompok eksperimen lebih tinggi dibandingkan skor kualitas hubungan sosial pada kelompok kontrol $(\mathrm{t}=2.30, \mathrm{p}<0.05)$.
\end{abstract}

Kata Kunci : hubungan interpersonal, komunikasi interpersonal, mahasiswa tahun pertama 


\begin{abstract}
Abstrack
Eventhough it is said that men was a perfect human being, men also has limitation. People everywhere develop social interaction to satisfy their need for affections and completed their limitation. Social relation in the first-year college sudents plays as a crusial part because its has importance impacts to students success and well-being. Many studies has proved that quality of social relationship can be improved through interpersonal communication. The purpose of this study was to investigate the effectiveness of an interpersonal communication skill training to improve quality of social relationship among first-year students of IAIN Salatiga. This study was quasi-experimental. The number of participant in the experiment group were 21 (7 male and 14 female) and 20 (9 male and 11 female) in control group. Finding showed that interpersonal communication skill training increased the quality of interpersonal relashionship among first-year students of IAIN Salatiga significantly. There's a difference quality of interpersonal relationship score after the treatment, that experiment group has higher score than control group's $(t=2.30, p<0.05)$.
\end{abstract}

Keywords : interpersonal relationship, interpersonal communication, first-year college students

\title{
A. Pendahuluan
}

Manusia pada dasarnya adalah makhluk yang senang berteman. Dorongan untuk berinteraksi atau menjalin relasi dengan orang lain merupakan fitrah dasar manusia, dimana interaksi atau hubungan sosial dibentuk dalam pengalaman hidup manusia sehari-hari (Parameswari, 2015: 2).

Hubungan interpersonal yang berkelanjutan tergantung seberapa baik hal tersebut berkaitan dengan tiga kebutuhan dasar, yaitu keinginan untuk memberi dan mendapatkan kasih sayang, keinginan untuk menjadi bagian dari kelompok sosial tertentu, dan kebutuhan untuk memengaruhi seseorang atau peristiwa kehidupan. Pada mahasiswa baru, kebutuhan-kebutuhan tersebut meningkat. Untuk memenuhi kebutuhan-kebutuhan tersebut mahasiswa baru perlu memiliki kemampuan membina hubungan interpersonal yang baik (Yoon, Kim \& Kim, 2011: 805).

Penelitian Geng \& Midford (2015: 1) menunjukkan bahwa mahasiswa baru memiliki tingkat stres paling tinggi dibandingkan mahasiswa tingkat lainnya. Hasil 
identifikasi dari beberapa hali yang dirujuk oleh Geng \& Midford menunjukkan bahwa salah satu faktor yang menimbulkan stres adalah kesiapan sosial dan akademik untuk bekerja sama atau menjalin relasi dengan dosen pengampu dan sesama mahasiswa. Proses relasi antar teman dan dosen dianggap sebagai hal yang penting namun tidak cukup mudah untuk dilakukan.

Menurut Friendlander, dkk (2007 dalam Astini, 2011: 15), terdapat tiga area penting yang berpengaruh dalam masa transisi ini, yaitu penyesuaian dalam bidang akademik, sosial dan emosi. Dalam penyesuaian akademik, mahasiswa diharapkan mampu memahami sistem pembelajaran dan sistem penilaian yangn berbeda dibandingkan dengan sisitem akademik yang berlaku pada pendidikan menengah. Penyesuaian dalam area sosial menuntut mahasiswa untuk dapat membangun relasi dengan individu-individu lain dengan sifat dan sikap yang beragam. Proses tersebut bukanlah suatu hal yang mudah, namun penuh tantangan dan kadang menimbulkan persoalan pada diri mahasiswa beru. Terlebih lagi jika mahasiswa tersebut berasal dari tempat yang cukup jauh dari kampus (berbeda daerah asal mahasiswa).

Pentingnya hubungan antar pribadi bagi mahasisiwa dalam proses pembelajaran atau setting kehidupan kampus telah banyak diteliti. Yoon, Kim \& Kim (2011: 811) menjelaskan bahwa mahasiswa berada pada tahap perkembangan individu dimana kualitas kognisi dan berkembangnya rasa memiliki (sense of belonging) suatu hubungan yang harmonis dengan teman sebaya menjadi faktor yang penting. Keterampilan membina relasi sosial dapat memengaruhi tercapainya kesehatan dan kepuasan sosial serta kualitas kehidupan pekerjaan / karir setelah mahasiswa lulus. Penelitian Rahmawati \& Yani (2014: 104) menunjukkan bahwa ada hubungan antara interaksi sosial dengan hasil belajar mahasiswa ( $r x y=0,440$ ) dimana interaksi sosial memberikan kontribusi sebesar 44\% terhadap hasil belajar mahasiswa. Wellar (2015: 105) bahwa untuk mendapatkan kesuksesan, mahasiswa baru perlu memiliki kualitas akademik dan integrasi sosial yang tinggi. Mahasiswa yang memiliki integrasi sosial dengan lingkungan (teman kuliah, dosen) yang baik mampu bertahan dengan baik dalam mengikuti perkuliahan hingga tahun keempat dan menyelesaikan perkulihan dengan baik. Mahasiswa yang memiliki relasi sosial yang tinggi lebih mampu bertahan menghadapi situasi yang sulit yang mungkin muncul dalam proses perkuliahan.

Dibalik pentingnya membina hubungan/relasi sosial yang baik terutama bagi mahasiswa baru, banyak mahasiswa yang mengalami kesulitan dalam 
memiliki keterampilan tersebut atau memiliki keterampilan membina hubungan sosial yang kurang/belum baik. Berdasarkan pengalaman peneliti sebagai psikolog di Biro Konsultasi Psikologi Tazkia IAIN Salatiga, banyak mahasiswa datang konsultasi dengan masalah relasi sosial, baik dengan teman maupun dengan dosen. Beberapa konselor yang juga bekerja di Biro Konsultasi Psikologi Tazkia IAIN Salatiga juga menyampaikan hal yang hampir sama. Keluhan tentang hubungan dengan teman paling banyak disampaikan oleh mahasiswa baru yang tinggal di pondok, asrama mahasiswa dan dikos-kosan. Bentuk persoalan hubungan sosial lain pada mahasiswa baru yaitu adanya perasaan cemas, takut, atau tidak tahu caranya memulai ketika harus bertemu atau berkomunikasi dengan dosen.

Berdasarkan informasi yang diberikan oleh konselor di Biro Konsultasi Psikologi Tazkia IAIN Salatiga, akar persoalan munculnya persoalan dalam membina relasi sosial yang baik adalah keterampilan komunikasi antarpribadi atau komunikasi interpersonal. Bentuk-bentuk persoalan komunikasi interpesonal misalnya berselisih pendapat dengan teman, salah paham hingga ada yang sampai berseteru terbuka ataupun pertengkaran melalui media sosial (cyber-war). Bentuk lain yang muncul sebagai masalah yang dihadapi mahasiswa baru misalnya tidak mampu menyatakan perasaannya atau ketidak setujuannya dan memilih untuk memilih diam dan mendiamkan persoalan yang muncul hingga persoalan tersebut berlalu atau berkurang sendiri intensitasnya. Menurut Dehaghani, Akhormeh \& Mehrabi (2012: 291), Wood (2013: 96), Yilzid \& Duy (2013: 1470) dan Payton (2018: 269), kondisi demikian merupakan indikator dari kemampuan komunikasi interpersonal yang rendah/kurang baik.

Komunikasi interpersonal dapat didefinisikan sebagai proses psikologis dimana terdapat dua individu atau lebih yang saling berhubungan dan terbuka dalam hal berbagi informasi, emosi, gagasan dan pengalaman-pengalaman yang dialami individu tersebut (Kaya, dalam Yilzid \& Duy, 2013: 1472). Dehaghani, Akhormeh \& Mehrabi (2012) dan Payton (2018) menyarakankan untuk meningkatkan relasi sosial yang harmonis (baik) individu-indidu perlu memahami dan memiliki keterampilan komunikasi interpersonal. Pendapat senada dikemukakan oleh Kumar (2017: 51) yang menyebutkan bahwa keterampilan komunikasi interpersonal merupakan suatu hal yang krusial pada diri setiap manusia, karena akan membantu pemenuhan kebutuhan untuk berinterasi dengan orang lain. Komunikasi interpersonal yang memuaskan dapat mempererat ikatan sosial. 
Rogers (dalam Hanani, 2017: 23) menjelaskan bahwa sutu hubungan yang sehat dapat digambarkan melalui sifat yang mencirikan komunikasi interpesonal yang positif, yaitu pelaku komunikasi saling merasa dan dapat mengandalkan satu sama lain; mengungkapkan diri secara jelas; memiliki sikap positif dan perhatian kepada orang lain; memiliki identitas satu sama lain; hubungan ditandai dengan adanya empati/mencoba saling memahami; tercipta lingkungan yang menyenangkan; membangun penilaian yang disukai orang lain dan berperilaku luwes.

Pengetahuan dan keterampilan bagaimana membina hubungan sosial dan komunikasi interpersonal yang baik dirasa sangat diperlukan oleh mahasiswa baru pada umumnya dan secara khusus pada mahasiswa IAIN Salatiga, mengingat masyarakat Salatiga dan orang-orang yang tinggal di Salatiga merupakan masyarakat yang beragam budaya. Melalui studi literatur, Masturi (2010: 14) juga memaparkan tentang pentingnya membangun relasi sosial melalui komunikasi empatik. Hanya saja dalam studi Mastur (2010: 14) belum disampaikan hasil uji empirisnya.

Berdasarkan paparan diatas, peneliti tertarik untuk meneliti pengaruh pelatihan komunikasi interpersonal terhadap kualitas relasi sosial pada mahasiswa baru di lingkup IAIN Salatiga. Rumusan persoalan yang dikemukakan dalam penelitian ini adalah "Apakah ada pengaruh pelatihan komunikasi interpersonal terhadap kualitas hubungan sosial pada mahasiswa baru di IAIN Salatiga ? Bagaimanakah pengaruh pelatihan komunikasi interpersonal terhadap kualitas hubungan sosial pada mahasiswa baru di IAIN Salatiga"

Berdasarkan tinjauan teori yang telah dipaparkan, peneliti mengajukan hipotesis : a) Pelatihan komunikasi interpersonal dapat meningkatkan kualitas hubungan sosial pada mahasiswa baru di IAIN Salatiga; b) Pada mahasiswa yang mengikuti pelatihan komunikasi interpersonal, terdapat peningkatan kualitas hubungan sosial sebelum pelatihan dan setelah pelatihan.

Variable tergantung : kualitas hubungan sosial pada mahasiswa baru, yaitu suatu kapasitas yang dimiliki oleh individu (mahasiswa baru) dalam membina hubungan dengan orang lain yang mengarah pada berkembangnya sikap toleransi dan memahami perbedaan individu serta mampu menjalin keintiman/keakraban. Adapun untuk Variabel bebas : pelatihan komunikasi interpersonal, yaitu serangkaian kegiatan pembelajaran tentang pengembangan keterampilan komunikasi interpersonal. Adapun materi yang dipelajari dalam pelatihan ini yaitu Konsep-konsep dasar komunikasi interpersonal, Membina komunikasi 
interpersonal yang baik, Memahami dan mengembangkan keterampilan komunikasi verbal dan non-verbal, Memahami dan mengembangkan keterampilan mendengar aktif, Memahami dan mengembangkan kemampuan empati dan Kemampuan mengungkapkan emosi/perasaan (Asertifitas).

Penelitian ini menggunakan metode eksperimen, yaitu quasi-experiment dengan jenis Nonequivalent Control Group Design. Desain eksperimen yang dilakukan adalah pengujian terhadap dua kelompok (eksperimen dan kontrol) baik sebelum dan sesudah perlakuan diberikan (pretest-posttest). Individu yang menjadi kelompok eksperimen adalah mahasiswa yang melamar sebagai peserta pelatihan. Adapun individu yang menjadi kelompok kontrol adalah mahasiswa semester satu yang mengikuti perkuliahan Histori Psikologi. Desain penelitiannya dapat divisualisasikan sebagai berikut :

Table 1. Rancangan desain penelitian

\begin{tabular}{lllll}
\hline Sampling & Group & Pretest & Treatment & Posttest \\
\hline Nonrandom & Eksperiment & P1 & T & P3 \\
\hline Nonrandom & Control & P2 & - & P4 \\
\hline
\end{tabular}

Subyek dalam penelitian ini terdiri atas kelompok eksperimen yang berjumlah 21 orang (7 laki-laki dan 14 perempuan), dan kelompok kontrol berjumlah 20 mahasiswa ( 9 laki-laki dan 11 perempuan). Subyek dalam kelompok eksperimen diperoleh dari proses pendaftaran. Sebelumnya peneliti mengeluarkan informasi (pengumuman terbuka) bahwa akan dilaksanakannya pelatihan komunikasi interpersonal bagi mahasiswa baru. Dalam pengumuman tersebut ditentukan jumlah kuota peserta maksimal yaitu 25 peserta. Penentuan jumlah kuota maksimal tersebut didasarkan pertimbangan untuk mencapai efektifitas pelatihan sebagaimana mana yang disarankan oleh Dehaghani, Akhormeh, \& Meharabi (2012: 291) bahwa jumlah partisipan pelatihan tidak lebih dari 25 orang.

\section{B. Pembahasan}

\section{Pengertian Kualitas Relasi Sosial}

Penjelasan tentang relasi sosial dalam penelitian ini menggunakan kajian teori dari istilah yaitu interaksi sosial, dan hubungan sosial. Interaksi sosial merupakan hubungan-hubungan sosial yang dinamis yang menyangkut hubungan 
antara orang perorangan, antara kelompok-kelompok manusia, maupun antara orang peroengan dengan kelompok manusia (Gillin \& Gillin dalam Soekanto \& Sulistyowati, 2012: 279). Syarat yang harus terpenuhi agar suatu interaksi sosial itu terjadi yaitu adanya komtak sosial dan komunikasi.

Duck \& Gilmour (dalam Budyatna \& Ganiem, 2011: 36) menjelaskan bahwa hubungan sosial dapat didefinisikan sebagai serangkaian interaksi antara dua individu yang saling kenal satu sama lain. Hubungan yang baik ialah dimana interaksi-interaksi yang sifatnya memuaskan dan sehat bagi mereka yang terlibat dalam interaksi tersebut. Hubungan yang baik tidak terjadi begitu saja dan juga tidak tumbuh dan terpelihara sesama otomatis. Hubungan tersebut memerlukan usaha. Sedangkan Yoon, Kim \& Kim (2011: 806) mendefinisikan kualitas hubungan sosial sebagai merupakan suatu proses interaksi dengan orang lain dimana dalam proses tersebut tercapai keseimbangan dalam diri individu dan tercipta hubungan yang harmonis dengan orang lain.

Hubungan sosial memiliki tingkatan dan unsur-unsur yang mendasari. Budyatna \& Ganiem (2011: 36) mengutip pendapat LaFollette, menyebutkan bahwa suatu hubungan antar individu dapat berbeda mengenai intensitasnya, dari yang tidak bersifat pribadi atau impersonal ke yang bersifat personal. Hubungan yang tidak bersifat pribadi (impersonal) ialah dimana seseorang berhubungan dengan orang lain semata-mata karena orang itu dapat mengisi peran atau memenuhi kebutuhan segera. Sedangkan hubungan pribadi atau personal relationship ialah dimana orang mengungkapkan informasi terhadap satu sama lain dan berusaha untuk memenuhi kebutuhan pribadi satu sama lain.

Agar hubungan antar pribadi berkembang dan berkesinambungan, terdapat beberapa persyaratan perilaku yang harus ada, yaitu kecakapan inisiasi (inisiation), mau mendengarkan (responsiveness), pengungkapan diri (selfdisclosure), dukungan emosional (emotional support) dan pengelolaan konflilk (conflict management). Suatu hubungan dapat terjalin dengan akrab ditandai oleh kadar yang tinggi mengenai keramahtamahan dan kasih sayang, kepercayaan, pengungkapan diri dan tanggung jawab

Chickering \& Reisser (dalam Aidoo, 2012: 13) menjelaskan kualitas hubungan sosial dengan menggunakan istilah kematangan hubungan antar pribadi (mature interpersonal relationships). Hubungan sosial yang matang merupakan suatu kondisi dimana individu memiliki kemampuan untuk menjalin relasi dengan orang lain dengan baik yang ditandai dengan adannya kemampuan toleransi (tolerance) dan memahami perbedaan antar individu (appreciation of difference) 
Upaya Meningkatkan Kemampuan Pengambilan Keputusan Karier Melalui Layanan Konseling Kelompok

serta adanya kemampuan untuk membina hubungan yang akrab atau intim (capacity for intimacy).

Dari penjelasan para ahli dapat disimpulkan bahawa kualitas hubungan sosial adalah suatu kapasitas yang dimiliki oleh individu dalam membina hubungan dengan orang lain yang ditandai dengan adanya kesediaan untuk mendengarkan, menginisiasi suatu proses komunikasi yang terbuka, dan tersedianya dukungan emosional sehingga hubunhan yang terbentuk mengarah pada berkembangnya sikap toleransi dan memahami perbedaan individu serta mampu menjalin keintiman/keakraban.

\section{Pelatihan Komunikasi Interpersonal}

Komunikasi interpersonal dapat didefinisikan sebagai proses psikologis dimana terdapat dua individu atau lebih yang saling berhubungan dan terbuka dalam hal berbagi informasi, emosi, gagasan dan pengalaman-pengalaman yang dialami individu tersebut (Kaya, dalam Yilzid \& Duy, 2013: 1470). Komunikasi interpersonal menurut Mulyana (2008, dalam Hanani, 2017: 21) adalah komunikasi antara orang-orang secara tatap muka yang memungkinkan sertiap pesertanya menangkap reaksi orang lain secara langsung, baik secara verbal maupu non-verbal. Karakteristik khusus dari komunikasi ini adalah diadik (ada proses dua arah yang saling memengaruhi) yang melibatkan dua orang atau lebih, seperti dua sejawat, suami-istri, dua teman/sahabat dan lain-lain.

Menurut Hanani (2017: 22) komunikasi interpersonal /komunikasi antar pribadi adalah komunikasi yang dilakukan dengan akrab dan sangat mengenal antara orang-orang yang terlibat didalamnya. Ia berlangsung dalam skala jumlah orang-orang yang didalamnya terbatas dan kecil yang mana diantaranya lebih saling mengenal.

Komunikasi interpersonal sering disebut juga dengan dyadic communication, maksudnya yaitu komunikasi antara dua orang dimana terjadi kontak langsung dalam bentuk percakapan. Komunikasi jenis ini dapat berlangsung secara berhadapan muka (face-to-face) ataupun melalui media seperti telepon. Ciri khas dari komunikasi interpersonal adalah sifatnya yang dua arah atau timbal balik (two way communications). Komunikasi antar pribadi melalui tatap muka memiliki satu keuntungan karena melibatkan perilaku nonverbal, ekspresi wajah, jarak fisik, perilaku paralinguistik yang sangat menentukan jarak sosial dan keakraban (Liliweri, 1997: 54). 
Menurut Budyatna \& Ganiem (2011: 36) kecakapan komunikasi interpersonal dapat membantu individu memulai, membangun, dan memelihara hubungan yang sehat dengan orang lain. Pendapat senada juga dikemukakan oleh Kumar (2017: 51) bahwa keterampilan komunikasi interpersonal merupakan suatu hal yang penting dalam kehidupan manusia, didalamnya merefleksikan adanya kebutuhan untuk berinteraksi dengan orang lain. Komuniksi interpersonal dapat memperkuat ikatan sosial.

Berdasarkan paparan pendapat ahli tersebut, disimpulkan bahwa komunikasi interpersonal adalah proses bertukar informasi, gagasan, perasaan yang terjadi antara dua orang atau lebih dalam satu ikatan yang saling memengaruhi (diadik) dan terjadi dalam proses tatap muka.

\section{Materi Pelatihan Komunikasi Interpersonal}

Kompetensi atau keterampilan berkomunikasi bukan merupakan kemampuan yang dibawa seseorang sejak lahir dan juga tidak akan muncul secara tiba-tiba saat seseorang membutuhkannya. Ketrampilan tersebut harus dipelajari atau dilatih (Supratiknya, 1995: 10).

Banyak ahli yang telah melakukan kajian tentang efektifitas pelatihan komunikasi interpersonal yang baik/efektif yang dalam pemaparannya menjelaskan pula materi-materi yang dapat dilatihkan dalam pelatihan komunikasi interpersonal, antara lain Yoo, Kim \& Kim (2011: 806), Devito (2013: 1475), Yildiz \& Duy (2013: 1473), Suciati (2017: 10). Materi pelatihan dalam penelitian ini disusun berdasarkan pendapat para ahli tersebut, yaitu : a) Konsepkonsep dasar komunikasi interpersonal; b) Membina komunikasi interpersonal yang baik, c) Memahami dan mengembangkan keterampilan komunikasi verbal dan non-verbal serta manfaatnya dalam menunjang proses komunikasi interpersonal, d) Memahami dan mengembangkan keterampilan mendengar aktif (active listening); e) Memahami dan mengembangkan kemampuan empat; f) Kemampuan mengungkapkan emosi/perasaan (Asertifitas)

\section{Pelaksanaan Riset dan Pembahasan}

Pada saat pendaftaran, mahasiswa calon peserta pelatihan mengisi surat kesediaan (informed consent) mengikuti kegiatan hingga selesai dan mendapatkan penjelasan tentang rangkaian kegiatan yang akan dilaksanakan. Penelitian ini dilaksanakan dalam 6 pertemuan dimana masing-masing pertemuan dilaksanakan dalam waktu 90 menit. Tiap pertemuan mempelajari satu tema/materi pelatihan. 
Aturan dalam kegiatan pelatihan ini yaitu, setiap mahasiswa yang hadir dalam satu kali pertemuan akan mendapatkan reward, yaitu token berupa stiker yang dihargai sebesar Rp. 10.000,- Token diberikan diakhir sesi pelatihan. Token tersebut dapat ditukar dengan uang pada saat pelatihan berakhir (pertemuan keenam). Peserta mendapatkan reward uang sesuai dengan banyaknya token yang dimiliki oleh peserta. Hal ini dilakukan sebagai usaha menambah motivasi peserta dalam mengikuti pelatihan. Jumlah peserta pada awalnya berjumlah 25 orang. Pada pertemuan terakhir, peserta yang hadir berjumlah 21 orang. Analisis data menggunakan data dari 21 peserta yang hadir secara lengkap (6 pertemuan).

Materi pelatihan komunikasi interpersonal dalam penelitian ini terdiri atas enam materi sebagaimana telah dijelaskan sebelumnya dan dilakukan dalam enam sesi pembelajaran. Waktu yang dibutuhkan tiap sesi pelatihan adalah 90 menit. Aktivitas pelatihan dilakukan melalui ceramah, diskusi tanya jawab, pemutaran video yang relevan dengan topik pembelajaran, simulasi/melatihkan keterampilan yang dipelajari malalui bermain peran (role play), dan pemberian umpan balik dari fasilitator kepada peserta dari suatu materi yang dilatihkan.

Variabel yang akan diukur dalam penelitian ini ada kualiltas hubungan sosial. Kualitas hubungan sosial dalam penelitian ini diungkap melalui Skala Kematangan Relasi Interpersonal (Mature Interpersonal Relationship/MIR) yang dikembangkan oleh Chickering (dalam Waller, 2015: 798) yang telah diadaptasi oleh peneliti. Skala ini terdiri atas tiga aspek, yaitu kemampuan toleransi (tolerance), mengapresiasi perbedaan antar individu (appreciation of difference) serta adanya kemampuan untuk membina hubungan yang akrab atau intim (capacity for intimacy). Skor Skala Kematangan Relasi Interpesonal terdiri atas empat pilihan respon, yang bergerak dari 1 (sangat tidak sesuai), 2 (tidak sesuai), 3 (sesuai), hingga 4 (sangat sesuai).

Skala Kematangan Relasi Interpersonal sebelum ujicoba berjumlah 40 aitem. Hasil uji validitas instrument menunjukkan terdapat 10 aitem yang gugur. Dengan demikian, Skala Kematangan Relasi Interpersonal yang digunakan untuk analisis data berjumlah 30 aitem. Skor maksimal $=120$ sedangkan skor minimal = 30. Skala Kematangan Relasi Interpersonal yang digunakan dalam penelitian diambil dari skor koefisien reliabilitas yang cukup tinggi. Skor koefisien reliabilitas bergerak dari $0.786-0.911$ (kategori tinggi). 


\section{Analisis Data}

Sebelum uji hipotesis dilakukan, terlebih dahulu dilakukan uji normalitas untuk membuktikan apakah data yang diperoleh normal dan dapat diuji dengan menggunakan statistic parametrik. Uji normalitas menggunakan uji KolmogorovSmirnov. Hasil uji normalitas diketahui bahwa data terdistribusi normal.

Setelah dilakukan uji normalitas, data diuji dengan menggunakan t-test. Dasar pertimbangannya mengikuti pendapat Myers \& Hansen (2002: 72), jika desain eksperimennya menggunakan satu variabel bebas dengan dua kelompok dan data yang digunakan untuk mengungkap variabel bebas adalah skala interval dan rasio, maka uji statistik yang tepat adalah t-test. Analisis data dilakukan dengan bantuan perangkat lunak SPPS 17.0 for windows. Berdasarkan hasil analisis data diperoleh informasi sebagai berikut :

Tabel 3. Nilai rata-rata dan deviasi standar dari skor variabel relasi sosial pada kelompok kontrol dan kelompok eksperimen

\begin{tabular}{|l|c|c|c|c|c|c|c|}
\hline \multicolumn{1}{|c|}{ Stage } & Group & \multicolumn{2}{|c|}{ Experiment } & \multicolumn{2}{c|}{ Control } & \multicolumn{2}{c|}{$\begin{array}{c}\text { Result of t- } \\
\text { test }\end{array}$} \\
\cline { 3 - 8 } & & Mean & SD & Mean & SD & t-test & $\mathrm{P}$ \\
\hline $\begin{array}{l}\text { Baseline } \\
\text { (Pretest) }\end{array}$ & & 49.66 & 13.90 & 49.43 & 12.50 & 0.10 & 0.92 \\
\hline $\begin{array}{l}\text { Pasca } \\
\text { Treatment } \\
\text { (Posttest) }\end{array}$ & 57.53 & 13.50 & 49.40 & 12.75 & 2.30 & 0.02 \\
\hline $\begin{array}{l}\text { Skor paired t- } \\
\text { tes }\end{array}$ & $\mathrm{t}$ & \multicolumn{2}{|c|}{2.75} & \multicolumn{2}{|c|}{0.32} & & \\
\cline { 2 - 7 } & $\mathrm{P}$ & \multicolumn{2}{|c|}{0.009} & \multicolumn{2}{|c|}{0.69} & & \\
\hline
\end{tabular}

Hasil analisis data dengan independent t-test pada tahap baseline (sebelum perlakuan/hasil pretest) menunjukkan bahwa kualitas hubungan sosial pada kelompok eksperimen dan kelompok kontrol tidak ada perbedaan $(\mathrm{p}=0.92 ; \mathrm{p}>$ 0.05). Artinya sebelum mendapatkan pelatihan komunikasi interpersonal, kedua kelompok memiliki kualitas hubungan sosial yang relatif sama. Namun, setelah perlakuan, terdapat perbedaan hubungan sosial yang signifikan $(\mathrm{p}=0.02$; $\mathrm{p}<$ 0.05). Artinya setelah mendapatkan pelatihan komunikasi interpersonal, terdapat perbedaan skor kualitas hubungan sosial, dimana kualitas hubungan sosial pada kelompok eksperimen lebih tinggi dibandingkan dengan kualitas hubungan sosial. 
Skor paired t-test menunjukkan bahwa pada kelompok eksperimen, nilai rata-rata kualitas hubungan sosial memiliki peningkatan yang signifikan dibandingkan sebelum perlakuan ( $p=0.009 ; \mathrm{p}<0.01$ ). Artinya, terdapat peningkatan kualitas hubungan sosial pada kelompok eksperimen antara sebelum pelatihan dan setelah pelatihan. Pada kelompok kontrol, nilai rata-rata kualitas hubungan sosial tidak terdapat perbedaan yang signifikan antara sebelum pelatihan dan setelah pelatihan $(\mathrm{p}=0.69 ; \mathrm{p}>0.01)$.

Table 4. Jumlah dan prosentase subyek berdasarkan kategori skor Skala Kematangan Relasi Sosial sebelum dan setelah pelatihan

\begin{tabular}{|c|c|c|c|c|c|c|}
\hline \multirow[t]{2}{*}{ Tahap } & \multicolumn{3}{|c|}{$\begin{array}{l}\text { Kelompok eksperimen } \\
\text { (n= 21) }\end{array}$} & \multicolumn{3}{|c|}{$\begin{array}{l}\text { Kelompok Kontrol } \\
\qquad(n=20)\end{array}$} \\
\hline & Rendah & Sedang & Tinggi & Rendah & Sedang & Tinggi \\
\hline $\begin{array}{l}\text { Baseline } \\
\text { (Pretest) }\end{array}$ & $\begin{array}{c}5 \\
(24 \%)\end{array}$ & $\begin{array}{c}11 \\
(52 \%)\end{array}$ & $\begin{array}{c}5 \\
(24 \%)\end{array}$ & $\begin{array}{c}5 \\
(25 \%)\end{array}$ & $\begin{array}{c}11 \\
(55 \%)\end{array}$ & $\begin{array}{c}4 \\
(20 \%)\end{array}$ \\
\hline $\begin{array}{l}\text { Pasca } \\
\text { Treatment } \\
\text { (Posttest) }\end{array}$ & $\begin{array}{c}3 \\
(14 \%)\end{array}$ & $\begin{array}{c}10 \\
(48 \%)\end{array}$ & $\begin{array}{c}8 \\
(38 \%)\end{array}$ & $\begin{array}{c}4 \\
(20 \%)\end{array}$ & $\begin{array}{c}12 \\
(60 \%)\end{array}$ & $\begin{array}{c}4 \\
(20 \%)\end{array}$ \\
\hline
\end{tabular}

Berdasarkan table 4 diperoleh informasi bahwa pada tahap awal (baseline) jumlah subyek berdasarkan kategori skor kualitas hubungan sosial memiliki sebaran yang relatif setara antara kelompok eksperimen dengan kelompok kontrol. Namun pada tahap setelah perlakuan/pasca pelatihan, nampak terdapat peningkatan (perubahan jumlah subyek berdasarkan kategori) dimana pada kelompok eksperimen terjadi perubahan yang cukup signifikan pada kategori tinggi (bertambah 3 orang atau sebesar $14 \%$ ). Perubahan juga terjadi pada jumlah subyek yang berkategori rendah (berkurang 2 orang atau sebesar 10\%).

\section{Hasil Penelitian}

Hipotesis pertama yang diajukan dalam penelitian ini adalah pelatihan komunikasi interpersonal dapat meningkatkan kualitas hubungan sosial pada mahasiswa di lingkup IAIN Salatiga. Hasil analisis data dengan independent t-test pada tahap baseline (sebelum perlakuan/hasil pretest) menunjukkan bahwa kualitas hubungan sosial pada kelompok eksperimen dan kelompok kontrol tidak ada perbedaan ( $\mathrm{p}=0.92$; $\mathrm{p}>0.05)$.. Namun, setelah perlakuan, terdapat perbedaan kualita hubungan sosial yang signifikan $(\mathrm{p}=0.02 ; \mathrm{p}<0.05)$. Artinya setelah 
mendapatkan pelatihan komunikasi interpersonal, terdapat perbedaan skor kualitas hubungan sosial, dimana kualitas hubungan sosial pada kelompok eksperimen lebih tinggi dibandingkan dengan kualitas hubungan sosial. Dengan demikian hipotesisi yang diajukan terbukti bahwa pelatihan komunikasi interpersonal dapat meningkatkan kualitas hubungan sosial pada mahasiswa di lingkup IAIN Salatiga. Hasil penelitian ini sejalan dengan pendapat Budyatna \& Ganiem (2011: 36) bahwa kecakapan komunikasi interpersonal dapat membantu individu memulai, membangun, dan memelihara hubungan yang sehat dengan orang lain.

Erozkan (2013: 739) menyebutkan bahwa penggunaan komunikasi interpersonal yang efektif merupakan hal yang penting dalam pengembangan hubungan antar pribadi, sebagai salah satu indikator kompetensi antar pribadi. Dalam kompetensi antar pribadi dibutuhkan kemampuan untuk dapat terlibat secara aktif dalam interaksi sosial yang kompleks dan perlu memiliki kemampuan memahami orang lain dengan baik. Individu yang memiliki hubungan sosial yang baik memiliki juga dapat memengaruhi orang lain, mampu berbagi pengetahuan dan perasaan dengan baik dan telibat dalam aktifitas bersama. Semua hal itu dapat dilakukan karena individu memiliki keterampilan komunikasi interpersosial yang baik atau efektif. Tanpa kemampuan komunikasi interpersonal yang baik atau efektif, pesan-pesan yang disampaikan dapat berubah menjadi masalah, kesalahpahaman ataupun frustrasi. Masalah-masalah dalam hubungan sosial dapat muncul ketika pesan atau informasi dipahami sengan salah. Penelitian Erozkan sendiri menunjukkan bahwa keterampilan komunikasi interpersonal memberikan sumbangan sebesar 22\% terhadap pemecahan masalah interpersonal yang selanjutnya memberikan pengaruh terhadap tingkat efikasi diri nahasiswa dalam membina hubungan sosial yang baik.

Hipotesis kedua yang diajukan dalam penelitian ini adalah pada mahasiswa yang mengikuti pelatihan komunikasi interpersonal, terdapat peningkatan kualitas hubungan sosial antara sebelum pelatihan dan setelah pelatihan. Hasil analisis data pada skor paired t-test menunjukkan bahwa pada kelompok eksperimen, nilai rata-rata kualitas hubungan sosial memiliki peningkatan yang signifikan dibandingkan sebelum perlakuan ( $\mathrm{p}=0.009 ; \mathrm{p}<0.01$ ). Artinya, terdapat peningkatan kualitas hubungan sosial pada kelompok eksperimen antara sebelum pelatihan dan setelah pelatihan. Pada kelompok kontrol, nilai rata-rata kualitas hubungan sosial tidak terdapat perbedaan yang signifikan antara sebelum pelatihan dan setelah pelatihan $(\mathrm{p}=0.69 ; \mathrm{p}>0.01)$. Dengan demikian, dapat 
disimpulkan bahwa hipotesis kedua terbukti, bahwa mahasiswa yang mengikuti pelatihan komunikasi interpersonal, terdapat peningkatan kualitas hubungan sosial pada sebelum pelatihan dan setelah pelatihan.

Berdasarkan analisis data juga diperoleh informasi bahwa pada tahap awal (baseline) jumlah subyek berdasarkan kategori skor kualitas hubungan sosial memiliki sebaran yang relatif setara antara kelompok eksperimen dengan kelompok kontrol. Namun pada tahap setelah perlakuan/pasca pelatihan, nampak terdapat peningkatan (perubahan jumlah subyek berdasarkan kategori) dimana pada kelompok eksperimen terjadi peningkatan yang cukup signifikan pada kategori tinggi (bertambah 3 orang atau sebesar $14 \%$ ). Perubahan juga terjadi pada jumlah subyek yang berkategori rendah (berkurang 2 orang atau sebesar 10\%). Dapat disimpilkan bahwa pelatihan komunikasi yang diikuti mahasiswa dapat meningkatkan kualitas mereka dalam mebina hubungan sosial dengan orang lain.

Keterampilan-keterampilan yang dilatihkan dalam penelitian ini yaitu dasar-dasar komunikasi interpersonal, kemampuan empatik, keterampilan mendengar aktif, keterampilan komunikasi verbal dan non verbal serta kemampuan mengungkapkan emosi/pikiran. Dengan dimilikinya sikap positif akan tercermin sikap dan perilaku menghargai orang lain, berpikiran positif tentang orang lain, tidak menuruh curiga secara berlebihan, memberikan pujian dan penghargaan serta komitmen dalam menjalin kerjasama (Suciati, 2017: 2). Dengan dimilikinya sikap atau kemampuan empati, dapat berkembang kemampuan memahami pikiran, perasan dan pengalaman orang lain. Kemampuan empati dapat membuat orang lain merasa, dimengerti, diterima dan dihargai (Yildiz \& Duy, 2013: 1474), sehingga dapat membuat orang menjadi lebih dekat dan akrab. Bahkan oleh Yildiz \& Duy disebutkan bahwa kemampuan empati merupakan kunci penting yang paling esensial dalam komunikasi interpersonal dan hubungan sosial. Mendengar secara aktif dapat membantu individu mengurangi hambatan-hambatan yang mungkin terjadi dalam proses komunikasi sehingga dapat mengurangi terjadinya masalah atau kesalahpahaman. Mendengar aktif dapat meningkatkan kualitas dan kepuasan hubungan antar pribadi (Payton, 2018: 270). Kemampuan mengungkapkan perasaan atau emosi dengan tepat dapat membantu individu lebih bahagia, karena dapat mengungkapkan perasaan dengan tepat tanpa membuat orang lain sakit hati atau marah. Johnson (dalam Supratiknya, 1995: 10-11) menjelaskan ada beberapa akibat negatif yang dapat muncul jika perasaan tidak diungkapkan, antara lain menyebabkan aneka masalah 
dalam hubungan antar pribadi, menyulitkan dalam memahami dan mengatasi masalah yang muncul antar pribadi, menimbulkan distorsi atau penyimpangan dalam penilaian serta melahirkan tuntutan-tuntutan diluar kemampuan individu. Yildiz \& Duy (2013:1471) menyarankan bahwa anak muda perlu belajar mengembangkan keterampilan strategi komunikasi interpersonal yang baik, karena dapat menciptakan hubungan antar pribadi yang efektif, sehat dan memuaskan, yang selanjutnya memengaruhi tingkat kepuasan hidup dan kepuasan terhadap diri individu sendiri.

Meskipun demikian, pengambilan kesimpulan tersebut perlu memprtimbangankan beberapa kelemahan dari penelitian ini. Penelitian ini mengandung kelemahan, antara lain data yang digunakan diperoleh dalam jumlah yang relatif kecil, meskipun penentuan jumlah tersebut digunakan sebagai pertimbangan mencapai efektifitas pelatihan. Selain itu, faktor pemilihan subyek yang belum dilakukan secara random, masih terbatas pada peserta pelatihan yang mendaftar mengikuti pelatihan. Saran bagi penelitian selanjutnya dapat melibatkan peserta yang lebih besar dan membuka kesempatan lebih luas kepada seluruh mahasiswa baru di lingkungan IAIN Salatiga atau perguruan tinggi lainnya.

\section{Simpulan}

Kesimpulan dari penelitian ini yaitu Pelatihan komunikasi interpersonal dalam penelitian ini dapat meningkatkan kualitas hubungan sosial pada mahasiswa baru di lingkungan IAIN Salatiga. Hal ini ditandai dari adanya perbedaan skor kualitas hubungan sosial pada mahasiswa yang mengikuti pelatihan dan yang tidak mengkuti pelatihan. Terdapat dua kategori hasil diantaranya 1) Mahaiswa yang mengikuti pelatihan komunikasi interpersonal memiliki skor kualitas hubungan sosial lebih tinggi dibandingkan mahaisiswa yang tidak mengikuti pelatihan; 2) Terdapat peningkatan kualitas hubungan sosial pada mahasiswa yang mengikuti pelatihan komunikasi interpersonal antara sebelum pelatihan dan sesudah pelatihan.

Meskipun terjadi peningkatan jumlah mahasiswa yang memiliki kualitas hubungan sosial dengan kategori tinggi, namun sebagain besar mahasiswa baru memiliki kualitas hubungan sosial dengan kategori sedang. Artinya diperlukan upaya lebih intensif lagi dalam mengembangkan keterampilan komunikasinya. Saran bagi lembaga, agar dapat membuat program psikoedukasi bagi mahasiswa baru, terutama dalam mengembangkan keterampilan komunikasi interpersonal. Adapun Saran bagi mahasiswa khususnya mahasiswa baru diharapkan dapat 
mengikuti pelatihan keterampilan komunikasi interpersonal baik yangn dilakukan di dalam kampus atau diluar kampus. Mahasiswa juga dapat proaktif belajar mandiri dengan membaca buku-buku ketermapilan komunikasi maupun bergabung dengan berbagai komunitas agar peluang lebih besar dalam mengaplikasikan ilmu yang diperoleh dalam penelitian ini.

Saran bagi peneliti lain agar dapat berhati-hati dalam mengambil keputusan, emngingat penelitian ini masih diterapkan pada subyek kecil. Disarankan bagi peneliti yang berminat mengembangkan penelitian in dapat menambah jumah subyek penelitian. Selain itu juga melibatkan variable-variabel lain seperti perbedaan jenis kelamin atau tempat tinggal. 


\section{DAFTAR PUSTAKA}

Aidoo, B. 2012. An examination of mature interpersonal relationships among international and american college students. Dissertation. The Unicersity of Southern Mississipi. Diunduh melalui :

https://aquila.usm.edu/cgi/viewcontent.cgi?article=1460\&context=dissertati ons pada 20 Desember 2018.

Al Nasseri, Y. S., Renganathan, L., Al Nasseri, F \& Al Balushi, A. 2014. Impact of students-Teacher relationship on Students's learning : A review of Literatur. Diunduh melalui

Astrini. Masa orientasi dan penyesuaian diri mahasiswa baru. Humaniora Vol.2 No.1 April 2011: 452-458. Diunduh melalui https://media.neliti.com/media/publications/167316-ID-masa-orientasidan-penyesuaian-diri-maha.pdf.

Budyatna, M. \& Ganiem, L.M. . 2011. Teori Komunikasi Antarpribadi. Jakarta: Kencana.

Dehaghani, A. R., Akhkormeh, K. A. \& Mehrabi, T. 2012. Assessimg the effectiveness of interpersonal communication skill training on job satisfaction among nurses in Al-Azhara Hospital od Isfahan Iran. Journal of Nursing and Midwifery Research, vol. 17(4). Diunduh melalui www.searchebscohost.com pada tanggal 14 Januari 2019.

DeVito, J. A. 2013. The interpersonal communication book. E-book. Diunduh melalui https://khmersharingdocuments.files.wordpress.com/2017/06/interpersona l-communication.pdf pada tanggal 20 Desember 2018.

Erozkan. A. 2013. The effect of Communication skills and interpersonal problem solving skills on social self-efficacy. Educational Sciences: Theory \& Practice. Diunduh melalui https://files.eric.ed.gov/fulltext/EJ1017303.pdf pada tanggal 2 Desember 2018.

Fanti. The parent-adolescent relationship and college adjustment over the freshman year. Thesis. Georgia State University. Diunduh melalui

http://scholarworks.gsu.edu/cgi/viewcontent.cgi?article=1003\&context=psych th eses pada tanggal 2 Desember 2018 
Fatnar, V. N \& Anam, C. 2014. Kemampuan interaksi sosial antara remaja yang tinggal di pondok pesantren dengan yang tinggal bersama keluarga. Empathy, vol. $2, \quad$ no.2, 71-75. Ddiunduh melalui http://journal.uad.ac.id/index.php/EMPATHY/article/view/3032/1768 pada tangga 2 Desember 2018.

Hanani, S. 2017. Komunikasi Antarpribadi: Teori dan Praktik.. Yogyakarta: Ar-Ruzz Media.

Gablinske, P. B. 2014. A Case study of students and teacher relationship and the effect on student learning. Diunduh melalui

$\underline{\text { https: } / / \text { digitalcommons.uri.edu/cgi/viewcontent.cgi?article }=1284 \& \text { context }=0}$ a diss

Geng, G \& Midford, R. 2015. Investigating first year education studentas' stress level. Australian Journal of Teacher Education vol. 40(6). Diunduh melalui https://files.eric.ed.gov/fulltext/EJ1064615 pada tanggal 20 Desember 2018.

Kronenenberger, J. L. 2012. Students Success : The effect of community college first-year course. Dissertation. Ohio: University of Dayton. Diunduh melalui https://etd.ohiolink.edu/!etd.send_file?accession=dayton1355257609\&dispo sition=inline pada tanggal 14 Januari 2019.

Kumar, R. 2017. Evaluastion of interpersonal communcication skill of the college students. International Journal of Marketing \& Financial Management, vol. 5(6), 51-58. Diunduh melalui https://zenodo.org/record/824863/files/p6i6v5ijmfm-Full\%20P-\%205158\%20Rakesh\%20Kumar\%20\%20\%20Jun-2017.pdf pada tanggal 2 Desember 2018.

Martin, A. J. 2014. Interpersonal Relationships and Students' Academic and NonAcademic Development: What Outcomes Peers, Parents, and Teachers Do and Do Not Impact. In D. Zandvliet., P. den Brok., T. Mainhard., \& J. Tartwijk (Eds). Interpersonal relationships in education: From theory to practice. Rotterdam: Sense Publishers. Diunduh melalui:

https://www.sensepublishers.com/media/1995-interpersonal-relationshipsin-education-5.pdf..

Masturi, A. 2010. Membangun relasi sosia melalui komunikasi empatik. Komunika, vol. 4, no. 1, 14-31. Diunduh melalui

http://ejournal.iainpurwokerto.ac.id/index.php/komunika/article/download /135/109 pada tanggal 2 Desember 2018. 
Maunder, R. E. 2018. Student's peer relationship and their contribution to university adjustment: The need to belonging in the university community. Abstrack. Journal of Further and Higher Education. Diunduh melalui

https://www.tandfonline.com/doi/abs/10.1080/0309877X.2017.1311996 pada tanggal 14 Januari 2019.

Myers, A. \& Hansen, C. H. 2002. Experimental Psychology. Fifth edition. California : Wadsworth.

Parameswari, J. 2015. Interpersonal relationship among College Students : an assessment. The International Journal of Indian Psychology vol. 2(2). Diunduh melalui

https://pdfs.semanticscholar.org/af2d/15edd83953fe9655535826c94dd54e 3c1932.pdf pada tanggal 29 Desember 2018.

Payton, J. 2018. Improving communication skills with the Nephrology Unit. Nephrology Nursing Journal, vol. 45, no. 3. Diunduh melalui xxx pada tanggal 20 Desember 2018. Diunduh melalui www.searchebscohost.com pada tanggal 14 Januari 2019.

Rahmawati, V. E \& Yani, D. P. 2014. Hubungan Interakdi sosial dengan hasil prestasi belajar mahasiswa semster IV Program Studi Diploma III Kebidanan UNIPDU Jombang. Diunduh melalui

http://www.journal.unipdu.ac.id/index.php/eduhealth/article/view/463.

Suciati. 2017. Komunikasi Interpersonal : Sebuah tinjauan psikologis dan perspektif Islam. Yogyakata: Buku Litera.

Uslu, F. \& Gizir, S. 2017. School belonging of Adolescents: The role of teacherstudents relationship, peer relationship and Family involevement. Educational Sciences: Theory and Practice, vol. 17 no. 1, 63-82. Diunduh melalui https://files.eric.ed.gov/fulltext/EJ1130860.pdf pada tanggal 2 Desember 2018.

Waller, B. 2015. Examining the mature interpersonal relationship status of firstyear engineering students within residential learning communities. Dissertation. Di unduh melalui https://mountainscholar.org/ bitstream/handle/ 10217/170385/ Waller colostate 0053A 13360.pdf? sequence $=1 \&$ is Allowed $=y$ pada 20 Desember 2018 .

Wardani, D. S. K. 2012. Pengaruh pelatihan komunikasi efektif untuk meningkatkan efikasi diri mahasiswa. Jurnal Psikologi Pendidikan dan Perkembangan vo. 1, no.

02.

Diunduh

melalui 
http://journal.unair.ac.id/filerPDF/110710233_3v.pdf pada anggal 2 Desember 2018.

Wood, J.T. Komunikasi Interpersonal: Interaksi Keseharian. (Terejemahan : Rio Dwi Setiawan). Jakarta: Salemba Humanika.

Yang, L. 2016. Interpersonal Relationship and the development of students interest in science. Electronic Journal of Science Education, vol. 20 no. 1. Diunduh melalui https://files.eric.ed.gov/fulltext/EJ1188261.pdf pada tanggal 14 Januari 2019.

Yildiz, M \& Duy, B. 2013. Improving emphaty and communication skills of visually impaired early adolescents through a Psycho-education Program. Education Science : Theory \& Practice, vol. 13(3), 1470 - 1476. Diunduh melalui: https://files.eric.ed.gov/fulltext/EJ1017646.pdf pada tanggal 20 Desember 2018.

Yoon, H.S., Kim, G. H. \& Kim, J. 2011. Effectiveness of an interpersonal relationship program on interpersonal relationship, self-esteem and depression in nursing students. Journal of Academic Nursing vol. 41 no. 6. Diunduh melalui https://www.researchgate.net/publication/221811263 Effectiveness of an I nterpersonal Relationship Program on Interpersonal Relationships Selfesteem and Depression in Nursing Students/download pada tanggal 20 Desember 2018. 